\title{
Kesulitan Siswa dalam Mengerjakan Soal-soal Eksponen dan Logaritma
}

\author{
Meta Silvia Gunawan ${ }^{1 *}$, Dian Fitra ${ }^{2}$ \\ 1*,2Fakultas Keguruan dan Ilmu Pendidikan, Universitas Adiwangsa Jambi \\ Jalan Sersan Muslim RT 24, Thehok, Jambi Selatan, Kota Jambi, Indonesia \\ ${ }^{1}$ metasilviagunawan@gmail.com; ${ }^{2}$ dian_fitra93@yahoo.co.id
}

Artikel diterima: 20-10-2020, direvisi: 09-05-2021, diterbitkan: 31-05-2021

\begin{abstract}
Abstrak
Fakta terdapat kesulitan dalam mengerjakan soal-soal eksponen dan logaritma menjadi latar belakang penelitian ini. Tujuan penelitian yaitu melihat kesulitan siswa dalam mengerjakan soal-soal eksponen dan logaritma. Subyek penelitian adalah 33 siswa di SMK Baiturrahim Jambi yang mengerjakan 7 soal materi eksponen dan logaritma. Selanjutnya dipilih 6 siswa yang masing2 mendapat skor sedang dan rendah untuk diwawancarai terkait kesulitannya dalam menyelesaikan soal tersebut. Metode kualitatif menjadi metode yang digunakan dalam penelitian. Pengumpulan data penelitian melalui Teknik observasi, tes soal, dan wawancara. Teknik analisis data yang dilakukan antara lain reduksi data, pengumpulan data, dan penarikan kesimpulan. Hasil tes siswa menunjukkan bahwa kesalahan terbanyak terjadi pada tahap transformation, dan process skill. Wawancara kemudian dilakukan untuk menggali lebih dalam faktor yang mempengaruhi kesulitan siswa. Ketiga faktor tersebut yakni faktor pengalaman, efektif, dan kognitif. Faktor kognitif menjadi faktor yang paling berpengaruh. Faktor kognitif sangat bergantung pada pemahaman siswa terhadap materi pada soal eksponen dan logaritma. Kata Kunci: Kesulitan Siswa, Eksponen, Logaritma, Metode Kualitiatif.
\end{abstract}

\section{Students' Difficulties in Solving Exponential and Logarithmic Test Items}

\begin{abstract}
The fact that there are difficulties in working on exponential and logarithmic problems is the background of this research. The research objective was to find out how difficult it was for students to solve exponential and logarithmic test items. The subjects used were 33 students of SMK Baiturrahim Jambi for doing the test, then 6 students were selected to be interviewed regarding their difficulties in solving those items. The research approach used in this analysis was qualitative. Observation, assessments, and interviews were used to gather data for this study. Data reduction, data collection, and conclusion drawing were the data analysis methods used. The results of the students' tests showed that most mistakes occurred in the transformation stage and process skills. Moreover, an interview was also conducted to know deeper into the factors that influenced students' difficulties. These three factors were experiential, affective, and cognitive factors. The cognitive factor was the most influential factor. The cognitive factor really depended on students' understanding of the material on the exponent and logarithmic test.

Keywords: Students' Difficulty, Exponential, Logarithmic, Qualitative Method.
\end{abstract}




\section{Pendahuluan}

Pendidikan adalah salah satu topik pembangunan berkelanjutan atau Sustainable Development Goals (SDG's) yang telah disepakati oleh forum Perserikatan Bangsa-bangsa (PBB) pada sidang umum ke 70 . Memastikan pendidikan yang inklusif dan berkualitas setara, juga mendukung kesempatan belajar seumur hidup adalah tujuan utama dari SDG's dalam bidang pendidikan (Abdurrahman, 2013; Suryadi, 2019). Terdapat 17 target pembangunan yang harus dicapai, salah satunya adalah tentang kualitas pendidikan itu sendiri. Kualitas pendidikan menjadi faktor untuk memajukan suatu Negara, karena dengan mutu Pendidikan yang baik dapat menciptakan sumber daya manusia yang mumpuni dalam membangun negara.

Sejak tahap sekolah dasar dan menengah, siswa diberikan pelajaran yang dapat menjadi bekal mereka untuk menghadapi hal-hal yang terjadi di dunia ini (Koivuniemi, Jarvenoja, \& Jarvela, 2018; Davydov, 2020). Selain sebagai mata pelajaran wajib, matematika juga menjadi pelajaran dasar bagi pelajaran lainnya. Lima alasan perlunya belajar matematika karena matematika merupakan 1) sarana berpikir yang jelas dan logis, 2) sarana untuk memecahkan masalah kehidupan sehari-hari, 3) sarana mengenal pola-pola hubungan dan generalisasi pengalaman, 4) sarana untuk mengembangkan kreativitas, dan 5) sarana untuk meningkatkan konsep, pembuktian, algoritma, penyelesaian soal, pemahaman ruang apresiasi dan keterampilan psikomotorik (Pinahayu, 2015). Dalam dunia pendidikan matematika, pemecahan masalah menjadi hal yang penting untuk ditanamkan pada diri peserta didik (Supita dkk, 2020). Kemampuan penalaran juga merupakan

kesadaran terhadap perkembangan budaya (Abdurrahman, 2013). paling signifikan dalam kehidupan individu. Siswa membutuhkan matematika ketika mereka lulus dari sekolah atau ketika mereka mulai bekerja (Tok \& Keskin, 2012). Untuk itu, pembelajaran matematika di sekolah harus lebih bermakna sehingga siswa lebih aktif dan mengerti tentang mata pelajaran yang diajarkan (Gunawan dkk, 2017). Meskipun penting, matematika dianggap sebagian besar siswa sebagai mata pelajaran yang sulit, membosankan, tidak praktis, abstrak, dan dalam pembelajaran membutuhkan kemampuan khusus yang tidak selalu dalam jangkauan setiap orang (Ignacio dkk, 2006). Kesulitan belajar merupakan suatu kondisi dimana prestasi yang dicapai tidak sesuai dengan kriteria standar yang telah ditetapkan, baik berbentuk sikap, pengetahuan maupun keterampilan (Subini, 2011).

Sering kali aspek-aspek dari pembelajaran matematika tidak muncul ketika pembelajaran di kelas dikarenakan siswa tidak mencerna pelajaran dengan baik. Aspek-aspek pembelajaran matematika di antaranya pemahaman 
salah satu kemampuan yang harus dikuasai siswa (Fitra dkk, 2018).

Berdasarkan beberapa penelitian terdahulu, terdapat fakta-fakta adanya kesulitan siswa dalam mengerjakan soal eksponen dan logaritma. Adanya kesalahan yang dilakukan siswa dalam menyelesaikan soal bentuk pangkat, akar dan logaritma terdiri dari kesalahan konseptual dan kesalahan procedural (Agustin \& Linguistika, 2012). Masih banyak siswa tidak selesai mengerjakan dikarenakan tidak memahami langkah pengerjaan yang menggunakan sifat logaritma (Hayati \& Budiyono, 2018). Hal ini mungkin disebabkan karena operasi pada logaritma berbeda dengan operasi pada bilangan real maupun bilangan bulat yang telah dikenal siswa waktu SMP (Hayati \& Budiyono, 2018).

Selain itu, materi sifat-sifat bilangan berpangkat tergolong materi yang sulit karena dalam penelitian terdahulu telah teridentifikasi banyak siswa yang melakukan kesalahan dalam menyelesaikan soal yang diberikan (Agustin \& Linguistika, 2012. Dalam penelitian Asy'ari (2015) juga diungkapkan bahwa penulisan rumus seringkali menjadi penyebab kesalahan, karena rumus yang diberikan oleh guru cenderung dihafal oleh siswa, tanpa memahami kontekstualitas rumus tersebut terhadap permasalahan sehari-hari (Ridia \& Afriansyah, 2019; Septiahani dkk, 2020).

Kesalahan siswa dalam mengerjakan soal perlu dianalisis untuk mengetahui kesalahan yang dilakukan siswa dan mengapa kesalahan tersebut dilakukan (Amalia, 2017). Kesalahan yang dialami siswa dalam menyelesaikan tugas matematika cenderung diakibatkan kurangnya penguasaaan konsep dan prosedur (Khair dkk, 2018). Kesalahan-kesalahan yang terjadi pada siswa dalam menyelesaikan soal dideskripsikan menggunakan Newman's Error Analysis (NEA). NEA merupakan tahapan untuk memahami dan menganalisis bagaimana siswa menjawab sebuah permasalahan yang ada pada soal. Newman (dalam White, 2010) menyatakan bahwa ketika siswa menjawab sebuah permasalahan pada soal, maka siswa tersebut telah melewati berbagai rintangan dalam menyelesaikan masalah yaitu; membaca masalah (reading), memahami masalah (comprehension), transformasi masalah (transformation), proses penyelesaian (process skill) dan penulisan kesimpulan (encoding) (Mulyadi dkk, 2015)

Identifikasi lanjutan pada kesulitan siswa dalam mengerjakan soal-soal eksponen dan logaritma perlu terus dilakukan. Diantara yang belum dilakukan oleh peneliti lain yaitu menganalisis berdasarkan faktor tertentu seperti faktor pengalaman, faktor efektif, dan faktor kognitif yang dialami siswa. Hal ini akan berguna untuk guru dalam merancang strategi dalam mengajarkan eksponen dan logaritma sehingga kemampuan siswa terkait dengan pemecahan masalah dalam eksponen dan logaritma dapat meningkat. Maka dari itu, penelitian ini dilakukan dengan tujuan 
menganalisis kesulitan siswa dalam mengerjakan persoalan pada materi eksponen dan logaritma dilihat dari faktor pengalaman, faktor efektif, dan faktor kognitif yang dialami siswa.

\section{Metode}

Metode penelitian yang digunakan dalam penelitian ini adalah metode kualitatif (Miles \& Huberman, 1992; Lesmana, Hidayat, \& Kosasih, 2018). Penelitian ini dilaksanakan di SMK Baiturrahim Kota Jambi. Subjek penelitian adalah siswa kelas $X$ Farmasi yang berjumlah 33 orang yang selanjutnya dibagi menjadi 2 kelompok yang berjumlah 16 orang dan 17 orang untuk 2 sesi kegiatan belajar mengajar (KBM). Pembagian kelompok belajar ini dilakukan sebagai tindakan preventif terkait penyebaran Covid-19.

Tahapan penelitian yang dilakukan yaitu melakukan studi pendahuluan terlebih dahulu dengan kesulitan siswa dalam memahami materi eksponen dan logaritma. Selain itu, peneliti juga melakukan observasi pada kegiatan belajar mengajar (KBM) untuk mengetahui cara belajar siswa di sekolah tersebut. Setelah itu, metode penelitian ditentukan, peneliti menentukan penelitian yang sesuai dengan fokus penelitian. Terakhir yaitu pengumpulan data. Peneliti menggunakan teknik tes yang terdiri dari soal eksponen dan logaritma yang digunakan sebagai instrumen penelitian, serta observasi dan wawancara untuk mengumpulkan data yang dapat menunjang menjawab rumusan masalah dalam penelitian ini. Data yang sudah terkumpul kemudian dianalisis. Analisis data dilakukan dengan cara mereduksi, menyajikan, lalu menarik kesimpulan dari data yang diperoleh (Miles \& Huberman, 1992). Data yang diolah merupakan hasil dari observasi, tes soal, dan wawancara pada siswa. Data tersebut disajikan agar dapat menjawab rumusan masalah pada penellitian ini. Proses penarikan kesimpulan merupakan bagian penting dari kegiatan penelitian karena merupakan kesimpulan dari penelitian. Kesimpulan yang diperoleh harus mampu menjelaskan apakah yang menjadi kesulitan siswa dalam menyelesaikan soal eksponen dan logaritma.

\section{Hasil dan Pembahasan}

\section{A. Analisis Kesalahan Jawaban Siswa}

Analisis kesalahan jawaban siswa dalam mengerjakan soal eksponen dan logaritma berdasarkan Prosedur Newman, dijelaskan sebagai berikut:

1. Kesalahan membaca soal (Reading error)

Kesalahan ini terjadi ketika siswa tidak mampu membaca atau mengenal symbol atau kata dalam soal dan siswa tidak mampu memaknai arti kata, istilah atau simbol dalam soal. Contoh kesalahan siswa dapat dilihat dari Gambar 1 berikut. 


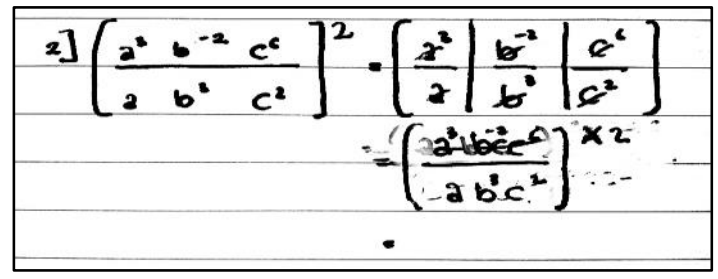

Gambar 1. Reading error pada soal eksponen.

Pada Gambar 1, dapat dilihat siswa tidak membaca soal dengan benar. Pada soal tertulis $\left(\frac{a^{3} b^{-2} c^{6}}{a b^{3} c^{2}}\right)^{2}$, sedangkan siswa tersebut tidak menuliskan pangkat 2 yang tercantum pada soal. Selanjutnya siswa melanjutkan pengerjaannya dengan hasil yang sama seperti soal yang diberikan, dengan menuliskan pangkat 2 yang sebelumnya tidak dicantumkan.

Pada soal logaritma, kesalahan siswa dalam membaca soal ini terjadi lebih banyak. Contoh kesalahan membaca soal logaritma dapat dilihat pada Gambar 2 berikut.

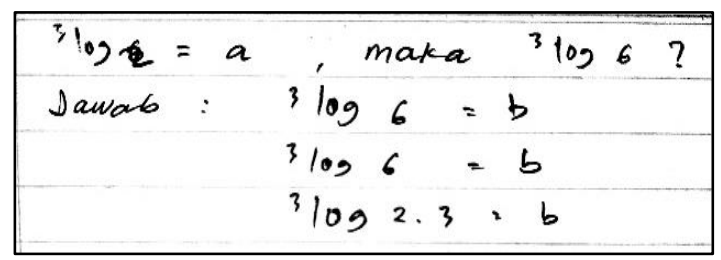

Gambar 2. Reading error pada soal logaritma.

Pada Gambar 2 terlihat bahwa adanya ketidakmampuan siswa dalam membaca soal dengan baik dan benar, informasi pada soal sama-sekali tidak digunakan dalam mencari jawaban. Siswa tidak mengerti kegunaan informasi dari ${ }^{3} \log 2=a$ dalam soal.

2. Kesalahan memahami masalah (Comprehension error)

Kesalahan ini biasanya terjadi ketika siswa sudah mampu membaca soal dengan benar, namun tidak mengetahui cara menyelesaikan soal tersebut. Meskipun siswa dapat menuliskan informasi pada soal dengan tepat, siswa tidak mampu untuk melanjutkan proses penyelesaian. Kesalahan ini dapat dilihat dari hasil jawaban siswa yang tidak sesuai dengan apa yang diminta pada soal. Contoh dari kesalahan ini, dapat dilihat pada Gambar 3 berikut.

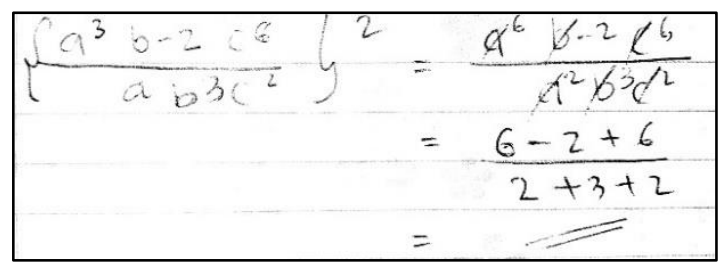

Gambar 3. Comprehension error pada soal eksponen.

Pada Gambar 3 terlihat bahwa siswa mampu membaca soal, namun kurang memahami makna dari soal tersebut. Siswa mengetahui bahwa jika konsep pecahan dapat dibagi habis, namun yang dituliskan siswa pada soal ini belum tepat. Siswa mencoret (menandakan terbagi habis), padahal pangkat dari variabel yang dicoret tidak sama. Selanjutnya untuk kesalahan siswa pada soal logaritma dapat dilihat dari Gambar 4 berikut.

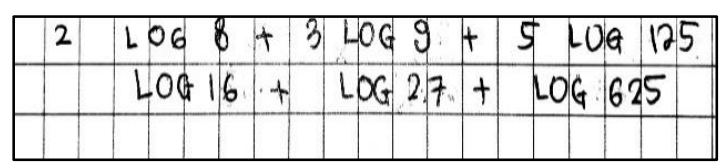

Gambar 4. Comprehension error pada soal eksponen. 
Pada Gambar 4 terlihat bahwa siswa keliru mengidentifikasi bentuk logaritma yang sebenarnya. Siswa menuliskan basis pada logaritma dengan ukuran besar.

3. Kesalahan transformasi masalah

(Transformation error)

Kesalahan transformasi terjadi ketika siswa sudah berhasil memahami masalah, namun keliru dalam mengubah soal ke dalam bentuk matematika yang benar. Contoh kesalahan siswa pada soal eksponen dapat dilihat dari Gambar 5 berikut.

$\begin{aligned} 5^{10} \times 5^{-4} \times 25^{-2} & =5^{10} \times 5^{-4} \times 5^{2} \times 5^{-2} \\ & =5^{10+(-4)+2+(-2)} \\ & =5^{6} \\ & =5 \times 5 \times 5 \times 5 \times 5 \\ & =625 .\end{aligned}$

Gambar 5. Transformation error pada soal eksponen.

Pada Gambar 5 terlihat bahwa siswa keliru dalam menjabarkan $25^{-2}$ yang dapat diubah menjadi $\left(5^{2}\right)^{-2}$. Sedangkan dari soal logaritma, kesalahan siswa dapat dilihat dari Gambar 6 berikut.

${ }^{2} \log 8+{ }^{3} \log 9+{ }^{5} \log 125$
$=8^{2}+9^{3}+125^{5}$
$=64+729+625$
$=1.518$

Gambar 6. Transformation error pada soal logaritma.

Dari Gambar 6 terlihat bahwa siswa belum mampu mengubah bentuk logaritma kedalam bentuk eksponen. Kesalahan ini banyak terjadi pada jawabanjawaban siswa.
4. Kesalahan keterampilan proses

(Process skill error)

Kesalahan pada tahap ini adalah saat siswa keliru dalam proses perhitungan, tidak dapat melanjutkan penyelesaian soal, dan salah konsep. Kesalahan ini dapat terjadi ketika siswa salah menentukan rumus. Dari jawaban siswa yang telah diperiksa, kesalahan ini paling banyak ditemukan. Salah satu contoh dari kesalahan ini dapat dilihat dari Gambar 7 berikut.

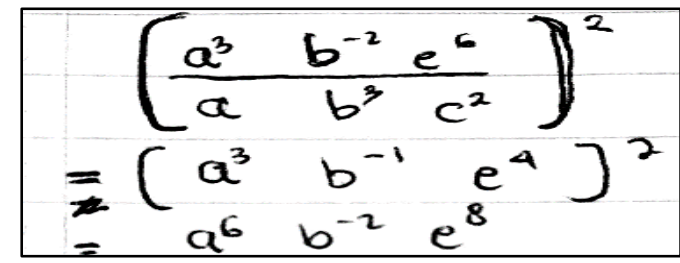

Gambar 7. Process skill error pada soal eksponen.

Pada Gambar 7, terlihat bahwa siswa salah melakukan perhitungan pangkat untuk b. Kesalahan lain, dapat dilihat dari Gambar 8 berikut.

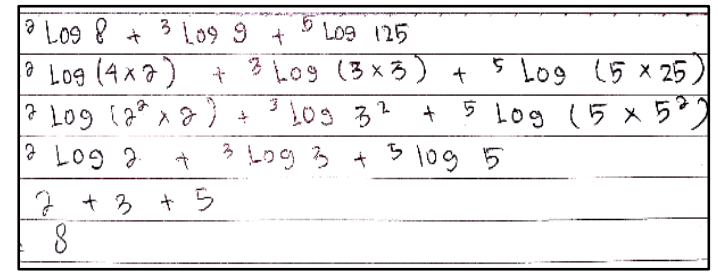

Gambar 8. Process skill error pada soal logaritma.

Pada Gambar 8 dapat dililhat bahwa siswa tidak memahami konsep logaritma. Penyelesaian dari jawaban baris tiga ke baris empat tidak tepat. Siswa tidak mampu menggeneralisasikan karena tidak mampu untuk menentukan metode yang digunakan (Muntikoh, 2017; Sari \& Afriansyah, 2020). Kesalahan ini menjadi 
kesalahan terbanyak, siswa tidak dapat melanjutkan proses penyelesaian jawaban dengan tepat.

5. Kesalahan penarikan kesimpulan (Encoding error)

Meskipun siswa berhasil memecahkan masalah, tetapi kesalahan masih bisa terjadi antara lain, siswa salah menuliskan apa yang dimaksud dalam jawaban akhirnya. Kesalahan ini juga terjadi karena siswa melakukan kesalahan dalam proses penyelesaian (Singh dkk, 2010). Contoh kesalahan siswa dapat dilihat dari Gambar 9 berikut.

$\begin{aligned} 5^{10} \times 5^{-4} \times 25^{-2} & =5^{104} \times\left(5^{2}\right)^{-2} \\ & =5^{46} \times 5^{-4} \\ & =\frac{5^{6}}{5^{-4}} \\ & =\frac{625}{20} \\ & =31 \frac{5}{20}=31 \frac{1}{4}\end{aligned}$

Gambar 9. Encoding error pada soal eksponen.

Pada Gambar 9, dapat dilihat bahwa siswa sudah benar sampai ke tahap keterampilan proses, namun siswa keliru dalam pembagian pada baris ke empat. Siswa juga keliru dalam penghitungan hasil akhir. Lalu, untuk contoh kesalahan ini pada soal logaritma, dapat dilihat dari Gambar 10 berikut.

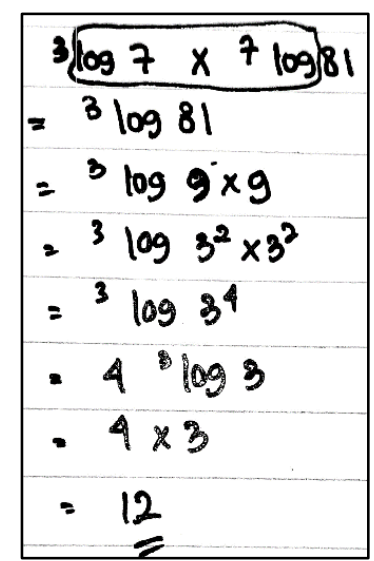

Gambar 10. Encoding error pada soal logaritma.

Jawaban pada siswa diatas keliru pada ${ }^{3} \log 3$ = 3 yang seharusnya hasilnya adalah 1. Pada tahap ini siswa gagal dalam menulis hasil akhir dengan benar.

\section{B. Analisis Hasil Wawancara Kesulitan Siswa}

Hasil wawancara pada penelitian ini juga membahas tentang faktor-faktor yang dapat mempengaruhi kemampuan siswa dalam mengerjakan soal. Dalam proses wawancara, peneliti menggali informasi kesulitan siswa yang dilihat dari faktor pengalaman, faktor efektif, dan faktor kognitif.

1. Faktor Pengalaman

Faktor pengalaman mencakup personal seperti usia, pengetahuan tentang penyelesaian masalah, pengetahuan isi dan konteks masalah. Salah satu hasil wawancara yang menunjukkan pengaruh faktor pengalaman dapat dilihat dari transkrip wawancara antara peneliti (P) dengan siswa (S) sebagai berikut:

$\mathrm{P}=$ Sebelum ujian kamu belajar ga? 
$\mathrm{S}=$ Dirumah ga sempat $\mathrm{Bu}$, disekolah sebelum jam masuk

$\mathrm{P}=$ Kenapa ga sempat di rumah?

$S=$ Saya jaga warung punya orang tua

$\mathrm{P}=$ Kalau yg belajar sebelum jam masuk ada mengerjakan contoh-contoh soal?

$\mathrm{S}=$ Tidak, saya hapal-hapalin rumus aja Bu

$\mathrm{P}=$ Pembelajaran yang disampaikan guru bagaimana menurut kamu?

$\mathrm{S}=$ Bingung Bu, kan karna Covid ini, jadi jamnya terpotong, sehingga buru-buru jelasinnya. Contoh yang di kasih ga terlalu banyak kayak gitu nah

$\mathrm{P}=$ Orang tua kamu selalu support kamu dalam bidang akademis? Dan dikasih fasilitas belajar yang baik ga di rumah? Misalnya buku rumusrumus gitu, terus disuruh les, gitu ga?

$\mathrm{S}=$ Dulu les pas SMP, sekarang karna korona jd ga les. Kalau buku-buku yang dari sekolah saja bu

Dari percakapan diatas terlihat bahwa siswa tidak memiliki pengalaman yang dapat diterapkan ketika mengerjakan soal. Siswa tidak mengulangi pembelajaran di rumah karena kurangnya waktu belajar yang diberikan oleh orang tua. Siswa juga merasa bahwa KBM yg berlangsung selama pandemik covid-19 membuatnya menjadi sulit mengerti penjelasan yang disampaikan guru. Hal ini terjadi karena siswa diharuskan menyelesaikan materi dalam waktu singkat, dimana jam belajar harus dibagi dengan siswa yang tergabung dalam sesi belajar selanjutnya. Sehingga pada KBM, guru tidak dapat memberikan contoh-contoh soal beragam yang dapat dijadikan siswa sebagai pengalaman belajar materi eksponen dan logaritma.

\section{Faktor Efektif}

Faktor efektif, misalnya minat, motivasi, tekanan kecemasan, toleransi terhadap ambiguinitas, ketahanan dan kesabaran. Salah satu hasil wawancara yang menunjukkan pengaruh faktor efektif dapat dilihat dari transkrip wawancara berikut:

$\mathrm{P}=$ Dari soal yg sudah kamu kerjakan, apa pendapat kamu tentang soal tersebut?

$S=$ Susah Bu ngerjainnya

$\mathrm{P}=$ Bukannya caranya sudah dijelaskan ketika belajar di kelas?

$\mathrm{S}=$ Ya tapi bingung

$\mathrm{P}=$ Kenapa tidak ditanyakan ke guru jika bingung?

$\mathrm{S}=$ Karna bingung juga mau nanya apa. Pas dijelaskan juga ndak ngerti Bu

$\mathrm{P}=$ Kamu suka belajar matematika ga?

$\mathrm{S}=\mathrm{Ga} \mathrm{Bu}$

$\mathrm{P}=$ Kenapa engga?

$\mathrm{S}=$ Karna saya lemah di hitung-hitung, saya sukanya menghapal

$\mathrm{P}=$ Nilai matematika selama ini bagaimana?

$\mathrm{S}=$ Hancur

$\mathrm{P}=$ Tanggapan orang tua tentang nilai kamu?

$\mathrm{S}=$ Biasa, karna sudah biasa, tau gitu bu kalau memang lemah matematika

Dari transkrip tersebut terlihat bawa siswa kurang termotivasi dalam mengerjakan soal matematika. Siswa tidak peduli dengan ketidakpahamannya terhadap materi tersebut. Peran orang tuapun sangat penting dalam hal mengatasi kesulitan siswa baik dalam belajar maupun dalam penyelesaian soal. Siswa yang mendapat motivasi baik dari dalam dirinya maupun lingkungannya, akan lebih berusaha dalam mencapai hasil yang baik.

3. Faktor Kognitif

Faktor kognitif meliputi kemampuan membaca, berwawasan (spatial ability), kemampuan menganalisis, keterampilan 
menghitung dan sebagainya. Salah satu hasil wawancara yang menunjukkan pengaruh faktor kognitif dapat dilihat dari transkrip wawancara berikut:

$\mathrm{P}=$ Kemarin kamu sudah mengerjakan soal ulangan yang sudah dikasih oleh guru, menurut kamu soal yang diberikan itu bagaimana?

$\mathrm{S}=$ Susah Bu

$\mathrm{P}=$ Oke, yang membuat kamu susah mengerjakannya apasih?

$\mathrm{S}=\mathrm{Ga}$ ngerti bu

$\mathrm{P}=$ Tidak ngertinya di bagian mana?

$\mathrm{S}=$ Lupa rumus-rumusnya, banyak sekali

$\mathrm{P}=$ Tapi untuk konsep dari eksponen dan logaritmanya kamu paham?

$\mathrm{S}=\mathrm{Ga}$ juga $\mathrm{Bu}$, masih bingung apa lagi yang logaritma itu

$\mathrm{P}=$ Kalau menurut kamu, eksponen itu apa sih? Dan Logaritma apa?

$\mathrm{S}=$ Eksponen pangkat 2

$\mathrm{P}=$ hanya pangkat 2 ?

$\mathrm{S}=$ eh, Pangkat-pangkat

$P=$ kalau logaritma?

$\mathrm{S}=$ Logaritma pangkatnya didepan, eksponen di belakang

Dari hasil wawancara yang dilakukan, siswa belum memahami konsep dari materi yang diberikan. Siswa tidak memahami bahwa logaritma adalah operasi kebalikan dari eksponensial. Siswa beranggapan perbedaannya terletak pada posisi pangkat. Dalam wawancara lain juga terlihat bahwa siswa tidak menguasai rumus operasi pada eksponen dan logaritma. Hal tersebut menjadi penyebab utama siswa sulit mengerjakan soal-soal yang diberikan. Dari wawancara yang dilakukan, faktor ini menjadi faktor yang menyebabkan mereka sulit dalam mengerjakan soal-soal yang diberikan. Siswa tidak menguasai materi dengan baik.

Berdasarkan uraian sebelumnya, diketahui kesalahan-kesalahan yang terjadi pada siswa dalam mengerjakan soal-soal eksponen dan logaritma, yang terdiri dari kesalahan membaca soal, kesalahan memahami masalah, kesalahan transformasi masalah, kesalahan keterampilan proses, dan kesalahan penarikan kesimpulan disebabkan oleh beberapa faktor. Diantaranya yaitu faktor pengalaman, faktor efektif, dan faktor kognitif, hal ini sejalan dengan penelitian Baskorowati \& Wijayanti (2020) dan Nanna, Pratiwi, \& Anggraeni (2020).

Faktor pengalaman menjadi penyebab kesulitan siswa karena siswa belajar dari sesuatu yang dikerjakanya. Kurangnya kesempatan belajar yang diberikan kepada siswa misalnya oleh orangtua di rumah atau guru di sekolah membuat pengalaman siswa menjadi kurang sehingga tidak memiliki cukup bekal pengetahuan untuk menyelesaikan masalah eksponen dan logaritma.

Faktor efektif yang terdiri dari minat, motivasi, dan lainnya berpengaruh pada keinginan siswa untuk belajar. Kurangnya stimulus baik dari orangtua, guru, atau lingkungan sekitar membuat siswa tidak tertarik untuk mempelajari suatu hal dengan baik. Hal ini berakibat pada munculnya banyak kesulitan siswa dalam belajar, termasuk mengerjakan soal eksponen dan logaritma. Selanjutnya faktor kognitif yg berkaitan dengan pengetahuan 
yang dimiliki siswa. Pemahaman siswa yang tidak baik terhadap materi akan menghambat siswa dalam menyelesaikan berbagai soal, termasuk eksponen dan logaritma.

\section{Penutup}

Kesulitan siswa dalam menjawab soal eksponen dan logaritma didasari beberapa faktor, yakni faktor pengalaman, faktor efektif, dan faktor kognitif. Faktor kognitif menjadi faktor yang paling berpengaruh dalam menyelesaikan soal-soal eksponen dan logaritma, karena faktor ini membahas tentang pemahaman materi oleh siswa.

Masalah siswa tidak menguasai materi, menimbulkan kesalahan-kesalahan dalam menyelesaikan soal eksponen dan logaritma. Kesalahan tersebut dari cara membaca soal yang tidak tepat, kurangnya pemahaman maksud dari soal, tidak bisa mentransformasi soal, kurangnya keterampilan proses saat mengerjakan Langkah-langkah dalam menjawab soal, dan tidak dapat menyimpulkan hasil pengerjaan soal.

Pemahaman materi dan perlunya waktu belajar yang tidak terburu-buru sangat diperlukan pada materi ini. Pemahaman materi dapat diasah melalui kegiatan pembelajaran yang melibatkan keaktifan siswa dalam menemukan konsep materi itu sendiri, lalu guru juga dapat memberikan Latihan soal lebih banyak untuk dikerjakan oleh siswa. Sehingga pembelajaran menjadi lebih bermakna, dan ketika diberikan soal, siswa dapat menyelesaikan dengan meminimalisir kesalahan kesalahan.

\section{UCAPAN TERIMA KASIH}

Penulis mengucapkan terimakasih kepada Dirjen Penguatan Riset dan Pengembangan KEMENRISTEKDIKTI yang telah membiayai penelitian ini melalui dana hibah Penelitian Dosen Pemula (PDP) tahun 2020.

\section{Daftar Pustaka}

Abdurrahman, M. (2013). Pendidikan bagi anak berkesulitan belajar. Jakarta: Rineka Cipta.

Agustin, K., \& Linguistika, Y. (2012). Identifikasi kesalahan siswa kelas $X$ pada evaluasi materi sifat-sifat bilangan berpangkat dengan pangkat bilangan bulat di SMA Muhammadiyah 2 Yogyakarta. Kontribusi Pendidikan Matematika dan Matematika Dalam Membangun Karakter Guru dan Siswa. Yogyakarta.

Amalia, S. R. (2017). Analisis Kesalahan Berdasarkan Prosedur newman dalam Menyelesaikan Soal Cerita Ditinjau dari Gaya Kognitif Mahasiswa. Aksioma, 8(1), 18-30.

Asy'ari, H. (2015). Analisis Kesalahan Siswa SMP Kelas VIII dalam Menyelesaikan Masalah Soal Cerita Matematika. Aksioma, 4(2), 10-17.

Baskorowati, H., \& Wijayanti, P. (2020). Studi Kasus: Analisis Kesalahan Siswa Dalam Menyelesaikan Soal Cerita Matematika Materi Sistem Persamaan 
Linear Tiga Variabel di SMA Negeri 1 Cerme.Jurnal IImiah Pendidikan Matematika Volume, 9(3).

Davydov, V. V. (2020). The psychological characteristics of the formation of elementary mathematical operations in children. In Addition, and Subtraction (pp. 224-238). Routledge.

Fitra, D., Putri, R. I. I., \& Susanti, E. (2018). Soal Serupa PISA menggunakan Konteks Cabang Olahraga Lari. Jurnal Inovasi Edukasi, 1(1), 8-22.

Gunawan, M. S., Putri, R. I. I., \& Zulkardi. (2017). Learning Fractions Through Swimming Context for Elementary School Students. Advances In Social Science, Education and Humanities Research 100.

Hayati, I. N., \& Budiyono. (2018). Analisis Kesulitan Siswa SMA Negeri 1 Kedungwuni Materi Logaritma. Journal of Mathematics and Mathematics Education, 8(2), 115-124.

Ignacio, N. G., Nieto, L. J. B., \& Barona, E. G. (2006). The Affective Domain in Mathematics Learning. International Electronic Journal Mathematics Education, 1(1), 94-111.

Khair, M. S., Subanji., \& Muksar, M. (2018). Kesalahan Konsep dan Prosedur Siswa dalam Menyelesaikan Soal Persamaan Ditinjau dari Gaya Berpikir. Jurnal Pendidikan: Teori, Penelitian, dan Pengembangan 3(5), 620-633.

Koivuniemi, M., Järvenoja, H., \& Järvelä, S. (2018). Teacher education students' strategic activities in challenging collaborative learning situations. Learning, culture and social interaction, 19, 109-123.

Lesmana, Y. Y., Hidayat, S., \& Kosasih, E. (2018). Penerapan Pendekatan Saintifik pada Kegiatan Menulis Teks Puisi di Kelas IV Sekolah Dasar (Penelitian Deskriptif Kualitatif di SD Negeri Mangkubumi dan SD Negeri 2 Cigantang Kecamatan Mangkubumi Kota Tasikmalaya). PEDADIDAKTIKA: Jurnal IImiah Pendidikan Guru Sekolah Dasar, 5(4), 121-132.

Miles, B., M., \& Huberman, M. (1992). Analisis Data Kualitatif Buku. Sumber Tentang Metode-metode Baru. Jakarta: UIP.

Mulyadi., Riyadi., \& Subanti, S. (2015). Analisis Kesalahan dalam Menyelesaikan Soal Cerita pada Materi Luas Permukaan Bangun DRuang Berdasarkan Newman's Error Analysis (NEA) Ditinjau dari Kemampuan Soasial. Jurnal Elektronik Pembelajaran Matematika, 3(4), 370382

Muntikoh, N. (2017). Strategi pembelajaran pencapaian konsep dalam pembelajaran matematika untuk meminimalisasi miskonsepsi matematika siswa (Bachelor's thesis).

Nanna, A. W. I., Pratiwi, E., \& Anggraeni, C. (2020). Analisis Kesalahan Mahasiswa Pgsd Dalam Menyelesaikan Masalah Geometri. SIGMA, 6(1), 66-77.

Pinahayu, E. A. R. (2015). Problematika Pembelajaran Matematika Pada Pokok 
Bahasan Eksponen dan Alternatif Pemecahannya. Jurnal Formatif, 5(3), 182-191.

Ridia, N. S., \& Afriansyah, E. A. (2019).

Perbandingan

Kemampuan

Pemahaman Matematis Siswa melalui

Auditory Intellectualy Repetition dan

Student Teams Achievement Division.

Mosharafa: Jurnal Pendidikan

Matematika, 8(3), 515-526.

Sari, H. M., \& Afriansyah, E. A. (2020)

Analisis MIskonsepsi Siswa SMP pada

Materi Operasi Hitung Bentuk Aljabar.

Mosharafa: Jurnal Pendidikan

Matematika, 9(3), 439-350.

Septiahani, A., Melisari., \& Zanthya, L. S.

(2020). Analisis Kesalahan Siswa SMK

dalam Menyelesaikan Soal Materi

Barisan dan Deret. Mosharafa: Jurnal

Pendidikan Matematika, 9(2), 311-

322.

Singh, dkk. (2010). The Newman Procedure

for Analyzing Primary Four Pupils Error

on Written Mathematical Task: A

Malaysian Perspective. Shah Alam:

University Technology MARA.

Subini, N. (2011). Mengatasi kesulitan belajar pada anak. Jogjakarta: Javalitera.

Supita., Nuryani, L. Z., \& Istiqomah. (2020).

Analisis Kesalahan Menyelesaikan Soal

Uraian Matematika Materi Logaritma

Kelas X SMK. Union, 8(1), 41-51.

Suryadi, S. (2019). Pengembangan

Lembaga Pendidikan sebagai

Organisasi Pengembangan Lembaga

Pendidikan

dan
Pembelajaran. IMPROVEMENT: Jurnal IImiah untuk peningkatan mutu manajemen pendidikan, 6(02), 28-44.

Tok, S., \& Keskin, A. (2012) The Effect of Fast Draw Learning Strategy on The Academic Achievement and Attitudes Towards Mathematics. International Journal of Innovation in Science and Mathematics Education, 1(20).

White, A. L. (2010). Numeracy, Literacy and Newman's Error Analysis. Journal of Science and Mathematics Education in Southeast Asia 2010, 33(2).

\section{Riwayat Hidup Penulis}

\section{Meta Silvia Gunawan, M.Pd.}

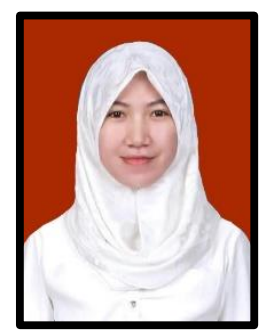

Lahir di Bandar Lampung, 22 Mei 1992. Saat ini terdaftar sebagai dosen tetap di Fakultas Keguruan dan IImu Pendidikan (FKIP) Universitas Adiwangsa Jambi. Penulis menyelesaikan S1 di Pendidikan Matematika FKIP Universitas Jambi, lulus pada tahun 2014; S2 di Pendidikan Matematika FKIP Universitas Sriwijaya, lulus pada tahun 2017.

Dian Fitra, M.Pd.

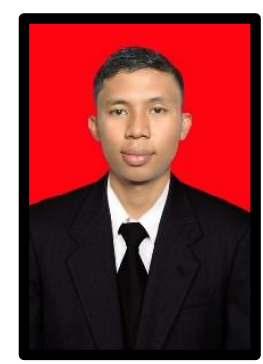

Lahir di Kerinci, 30 April 1993. Saat ini terdaftar sebagai dosen tetap di FKIP Universitas Adiwangsa Jambi. Penulis menyelesaikan S1 di Pendidikan Matematika FKIP Universitas Jambi, lulus pada tahun 2014; S2 di Pendidikan Matematika FKIP Universitas Sriwijaya, lulus pada tahun 2018. 